\title{
Hepatitis B, tropical ulcers, and immunisation strategy in Kiribati
}

\author{
C J TIBBS
}

\begin{abstract}
The seroepidemiology of hepatitis $B$ was studied in Kiribati (formerly the Gilbert Islands). Six hundred and two (98\%) of the population studied showed evidence of current or previous infection. The prevalence of hepatitis $B$ surface antigen was $31 \%$ $(188 / 615)$ and of the $e$ antigen was $9 \%(58 / 615)$. Infection was acquired early in life, and the prevalence of both antigens declined with age. The rates of infection were similar in all age groups examined (0-70) including early childhood. Both hepatitis $B$ surface antigen and e antigen were detected in exudates from tropical ulcers, which may be a source of environmental hepatitis B. Concordance of antigen presence was higher in pairs of siblings than in mother-child pairs.

All Gilbertese children should receive hepatitis B vaccine at birth or soon after if the long term consequences of hepatitis $B$ infection are to be minimised.
\end{abstract}

\section{Introduction}

Many studies have shown that there is a high prevalence of current or past infection with hepatitis B in the Pacific basin. The highest was recorded in the Polynesian population of Niue, where $12 \%$ of the adult population sampled carried hepatitis B antigen, and $83 \%$ had hepatitis B antibodies.' Only one study has examined a Micronesian population. This included Gilbertese people working as indentured labourers on Nauru. ${ }^{23}$ The rate of infection in young adults was high in this study, but the only data on hepatitis B in children in the Pacific come from Polynesian and Melanesian populations. ${ }^{45}$

Use of the recently available vaccines against hepatitis $B$ in developing countries may not only reduce the incidence of hepatitis

\footnotetext{
Department of Virology, St Thomas's Hospital Medical School, London SE1 7EH

C J TIBBS, MA, MB, medical student

Correspondence to: Dr C J Tibbs, Lister Unit, Northwick Park Hospital, Harrow, Middlesex HAl 3UJ
}

B infection but may also reduce the long term consequences of infection such as chronic liver disease and hepatocellular carcinoma ${ }^{67}$ In planning a vaccination strategy it is essential to know the age at which population members become infected and possible routes of infection.

This study investigated the seroepidemiology of hepatitis B in the Micronesian population of Kiribati, an isolated central Pacific community. It looked particularly at the age of infection and the carrier state of contacts. As tropical ulcers acquired from the coral reefs are common the presence of some hepatitis B markers in ulcer exudates was also assessed.

\section{Patients and methods}

\section{GEOGRAPHY}

The Republic of Kiribati (formerly the Gilbert Islands) is made up of 26 inhabited coral atolls that stretch for 300 miles on either side of the equator adjacent to the International Date Line. The total population is about 60000 , of whom 25000 live on the central island, Tarawa, which is the administrative capital. Two of the outer islands-Butaritari in the north and Nonouti in the south-with populations of about 3000 and 1800, respectively, were also studied to provide a widespread sample of the country's population.

\section{POPULATION STUDIES}

I collected the samples as part of a medical student elective in February and March 1984. It was not logistically possible to conduct a population census before the study, and, though every effort was made to reduce sampling bias, a random survey could not be conducted.

All blood samples were collected from volunteers. In Butaritari and Nonouti people attending village clinics or accompanying friends or relatives were asked to give blood. These clinics were run in conjunction with mother and child health clinics. On Tarawa samples came from three sourcesnamely, inpatients and outpatients at the island's two hospitals, prisoners at the central prison, and male trainees aged 17 to 23 , drawn from all the islands, studying at the marine training school. Table I shows the age and sex distribution of the populations studied. Though data on the whole population of Gilbertese adults have been published, ${ }^{8}$ there are no published data on the age and sex structure of children in Kiribati. Where possible, family relationships between subjects were traced and the presence or absence of tattoos noted. Exudate was taken from any ulcer seen. 
TABLE I-Age and sex distribution of populations studied

\begin{tabular}{|c|c|c|c|c|c|c|c|c|}
\hline \multirow[b]{2}{*}{ Population } & \multirow[b]{2}{*}{ Sex } & \multicolumn{6}{|c|}{ Age (years) } & \multirow[b]{2}{*}{ Total } \\
\hline & & $0-4$ & $5-9$ & $10-14$ & $15-24$ & $25-39$ & $\geqslant 40$ & \\
\hline Nonouti & $\begin{array}{l}M \\
F\end{array}$ & 3 & $\begin{array}{l}19 \\
15\end{array}$ & $\begin{array}{l}15 \\
15\end{array}$ & $\begin{array}{l}20 \\
20\end{array}$ & $\begin{array}{r}7 \\
15\end{array}$ & $\begin{array}{l}25 \\
28\end{array}$ & $\begin{array}{l}89 \\
93\end{array}$ \\
\hline Butaritari & $\stackrel{M}{\mathrm{~F}}$ & $\begin{array}{l}21 \\
16\end{array}$ & $\begin{array}{l}16 \\
15\end{array}$ & $\begin{array}{l}21 \\
18\end{array}$ & $\begin{array}{l}22 \\
35\end{array}$ & $\begin{array}{l}13 \\
39\end{array}$ & $\begin{array}{l}30 \\
39\end{array}$ & $\begin{array}{l}123 \\
162\end{array}$ \\
\hline $\begin{array}{l}\text { Tarawa: } \\
\text { Hospitals } \\
\text { Training school } \\
\text { Prison }\end{array}$ & $\begin{array}{l}M \\
F \\
M \\
M\end{array}$ & 2 & $\begin{array}{l}3 \\
4\end{array}$ & 10 & $\begin{array}{r}4 \\
11 \\
56 \\
8\end{array}$ & $\begin{array}{r}23 \\
7 \\
12\end{array}$ & $\begin{array}{l}5 \\
3\end{array}$ & $\begin{array}{l}37 \\
35 \\
56 \\
20\end{array}$ \\
\hline Totals & $\begin{array}{c}\mathbf{M} \\
\mathbf{F} \\
\text { Both }\end{array}$ & $\begin{array}{l}26 \\
16 \\
42\end{array}$ & $\begin{array}{l}38 \\
34 \\
72\end{array}$ & $\begin{array}{l}36 \\
43 \\
79\end{array}$ & $\begin{array}{r}110 \\
66 \\
176\end{array}$ & $\begin{array}{r}55 \\
61 \\
116\end{array}$ & $\begin{array}{r}60 \\
70 \\
130\end{array}$ & $\begin{array}{l}325 \\
290 \\
615\end{array}$ \\
\hline
\end{tabular}

\section{METHODS}

Collection of serum-Blood was collected with a plastic syringe and allowed to clot in glass containers. The serum was transferred with a disposable plastic pipette to small phials (FBG Trident) and frozen to $-5^{\circ} \mathrm{C}$ within six hours. After the survey had been completed the samples were transported to Hong Kong at $-5^{\circ} \mathrm{C}$ and placed on dry ice for return to England.

Collection of exudate from tropical ulcers-Exudates were drawn from the surface of any chronic ulcer with a disposable plastic micropipette, and any residual exudate was absorbed on clean tissue paper. These samples were treated in the same way as the serum. Exudate was eluted from the tissue paper with phosphate buffered saline before assay.

Assays-All samples were screened for hepatitis B antigen by radioimmunoassay (Ausria II, Abbott Laboratories, Chicago), and those found to be positive were tested for the presence of hepatitis $B$ e antigen and its antibody (AusAB, Abbott, Chicago). Serum that contained neither hepatitis $B$ antigen nor hepatitis $B$ surface antibody and in which the concentration of hepatitis B surface antibody was less than $50 \mathrm{IU} / \mathrm{ml}$ were screened for the presence of hepatitis B core antibody (Corzyme, Abbott, Chicago). If the volume of the sample was insufficient to allow this schedule to be followed the sample was discarded: 15 samples were excluded from further analysis in this way.

TABLE II-Number (\%) of people in Butaritari and Nonouti positive for hepatitis B surface antigen $(\mathrm{HBs} A \mathrm{~g})$

\begin{tabular}{|c|c|c|c|c|c|c|}
\hline & \multicolumn{6}{|c|}{ Age (years) } \\
\hline & $0-4$ & $5-9$ & $10-14$ & $15-24$ & $25-39$ & $\geqslant 40$ \\
\hline \multicolumn{7}{|c|}{ Men } \\
\hline $\begin{array}{l}\text { HBsAg positive: } \\
\text { Butaritari } \\
\text { Nonouti }\end{array}$ & $\begin{array}{c}11 / 21(52) \\
2 / 3(67)\end{array}$ & $\begin{array}{l}4 / 16(25) \\
4 / 19(21)\end{array}$ & $\begin{array}{l}6 / 21(29) \\
5 / 15(33)\end{array}$ & $\begin{array}{r}11 / 22(50) \\
8 / 20(40)\end{array}$ & $\begin{array}{l}5 / 13(38) \\
2 / 7 \quad(29)\end{array}$ & $\begin{array}{l}4 / 30(13) \\
5 / 25(20)\end{array}$ \\
\hline \multicolumn{7}{|c|}{ Women } \\
\hline $\begin{array}{l}\text { HBsAg positive: } \\
\text { Butaritari } \\
\text { Nonouti }\end{array}$ & $6 / 16(38)$ & $\begin{array}{l}4 / 15(27) \\
2 / 15(13)\end{array}$ & $\begin{array}{l}8 / 18(44) \\
6 / 15(40)\end{array}$ & $\begin{array}{l}7 / 35(20) \\
7 / 20(35)\end{array}$ & $\begin{array}{r}13 / 39(33) \\
5 / 15(33)\end{array}$ & $\begin{array}{l}8 / 39(21) \\
5 / 28(18)\end{array}$ \\
\hline
\end{tabular}

\section{Results}

Six hundred and fifteen subjects were studied, of whom $603(98 \%)$ showed evidence of active or previous infection with the hepatitis B virus $(95 \%$ confidence interval (CI) 96.9 to $98 \cdot 8$ ). The prevalence of hepatitis B surface antigen was $31 \%(188 / 615)(95 \% \mathrm{CI} 27 \cdot 8$ to $34 \cdot 1)$ and of hepatitis $\mathrm{B} e$ antigen $9 \%(59 / 615)(95 \%$ CI $7 \cdot 1$ to $11 \cdot 7)$. Hepatitis B antibody was present in 415 subjects $(67 \%)(95 \% \mathrm{CI} 63 \cdot 9$ to $70 \cdot 1)$. There were no real differences in age or sex specific prevalences of hepatitis $B$ surface antigen between the populations of Butaritari and Nonouti $\left(\chi^{2}=17 \cdot 3, \mathrm{df}=10, \mathrm{p}>0 \cdot 1\right)$ (table II) or between these islands and Tarawa in the age and sex groups from whom adequate samples were drawn (men aged 15-24 and 25-39) $\left(\chi^{2}=3 \cdot 0, \mathrm{df}=1\right.$, $\mathrm{p}>0.05$ ).

Table III shows the age and sex specific prevalences of antigen markers in the whole population. Though hepatitis B surface antigen was found most often in boys aged under 5 , there were no real differences among the age and sex groups $\left(\chi^{2}\right.$ for homogeneity $\left.=13.79, \mathrm{df}=10, p>0 \cdot 1\right)$. There was, however, a significant difference in the prevalence of hepatitis $B$ e antigen among age and sex groups $\left(\chi^{2}\right.$ for homogeneity $\left.=43.9, \mathrm{df}=10, \mathrm{p}<0.001\right)$, with a decline in prevalence with age. The greater prevalence of antigen in the youngest age group is reflected by a lower prevalence of antibody (table IV), but the overall prevalence of antibody and antigen did not vary among age and sex groups $\left(\chi^{2}\right.$ for homogeneity $\left.=0.9, \mathrm{df}=10, \mathrm{p}>0.5\right)$.

TABLE IV-Number (\%) of whole population carrying hepatitis B surface antibody and hepatitis $B$ core antibody

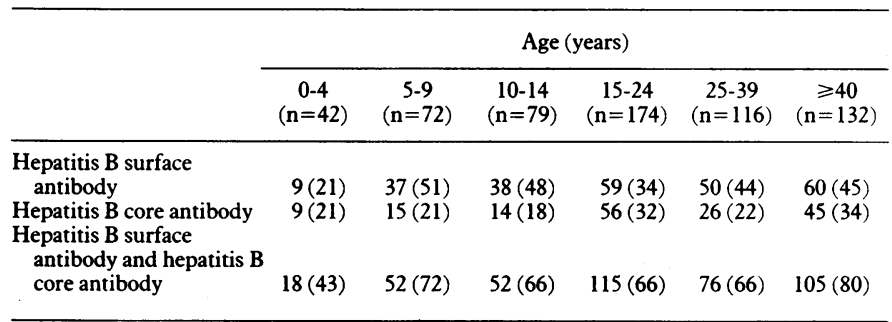

The possible routes of transmission investigated in this study were the intrapartum route from mother to child (vertical transmission), transmission between siblings, and transmission through the exudates of open ulcers. Data for transmission from mother to infant (table V) showed low concordance of presence of antigen in mother and infant. Though 23 of 44 of the children in this group were hepatitis B surface antigen carriers, of whom 14 also carried hepatitis B e antigen and a further 15 carried antibody, only 13 of the 44 mothers carried hepatitis B surface antigen, and only one was positive for hepatitis $B$ e antigen. There was no significant relation between the presence of antigen in children and its presence in their mothers $\left(\chi^{2}=1 \cdot 18, \mathrm{df}=1, \mathrm{p}>0 \cdot 1\right)$. In the population studied the prevalence of hepatitis $B$ e antigen among women of childbearing age (15-40 years) was low at $8 \%(10 / 127)(95 \% \mathrm{CI} 3 \cdot 1$ to $12 \cdot 4)$.

Much higher concordance of the presence of antigen was seen between older and younger siblings (table VI). This relation was significant $\left(\chi^{2}=9 \cdot 7\right.$, $\mathrm{df}=1, \mathrm{p}<0.01)$. Six of the eight younger siblings whose elder siblings carried hepatitis $\mathrm{B}$ e antigen were also positive for hepatitis $\mathrm{B} e$ antigen.

Ulcer exudates-Forty seven (8\%) of the subjects had ulcers, though many more had scars of old ulcers. Ten of these subjects carried hepatitis B surface antigen and two hepatitis B e antigen. Hepatitis B surface antigen was

TABLE III-Prevalence of hepatitis $B$ surface antigen and hepatitis $B$ antigen in whole population

\begin{tabular}{|c|c|c|c|c|c|c|c|c|c|c|c|c|}
\hline & \multicolumn{12}{|c|}{ Age (years) } \\
\hline & \multicolumn{2}{|r|}{$0-4$} & \multicolumn{2}{|r|}{$5-9$} & \multicolumn{2}{|r|}{$10-14$} & \multicolumn{2}{|r|}{$15-24$} & \multicolumn{2}{|r|}{$25-39$} & \multicolumn{2}{|r|}{$\geqslant 40$} \\
\hline & No & $\%(95 \% \mathrm{CI})$ & No & $\%(95 \% \mathrm{CI})$ & No & $\%(95 \% \mathrm{CI})$ & No & $\%(95 \% \mathrm{CI})$ & No & $\%(95 \% \mathrm{CI})$ & No & $\%(95 \% \mathrm{CI})$ \\
\hline \multicolumn{13}{|c|}{ Hepatitis B surface antigen: } \\
\hline Men & 14 & $54(32$ to 76$)$ & 9 & $24(12$ to 36$)$ & 11 & 31 (17 to 45$)$ & 40 & 37 (27 to 47$)$ & 21 & 38 (26 to 50$)$ & 12 & 19 (9 to 29$)$ \\
\hline Women & 6 & 38 (14 to 62$)$ & 7 & $21(9$ to 33 & 15 & 35 (21 to 49$)$ & 18 & 27 (17 to 37$)$ & 22 & 36 (24 to 48$)$ & 13 & 19 (11 to 27$)$ \\
\hline \multicolumn{13}{|c|}{ Hepatitis $B$ e antigen: } \\
\hline Men & 11 & 42 & 8 & 21 & 3 & 8 & 13 & 12 & 1 & 2 & & \\
\hline Women & 4 & 25 & 4 & 12 & 4 & 9 & 5 & 8 & 5 & 8 & 1 & 1 \\
\hline \multicolumn{13}{|c|}{ Total sample: } \\
\hline Men & 26 & & 38 & & 36 & & 108 & & 55 & & w2 & \\
\hline Women & 16 & & 34 & & 43 & & 66 & & 61 & & 70 & \\
\hline
\end{tabular}


TABLE V-Concurrence of hepatitis B markers in mothers and children (figures are numbers of mother-child pairs)

\begin{tabular}{|c|c|c|c|c|c|}
\hline \multirow[b]{2}{*}{ Children } & \multicolumn{4}{|c|}{ Mothers } & \multirow[b]{2}{*}{ Total } \\
\hline & Hepatitis B surface antigen & $\begin{array}{l}\text { Hepatitis B surface antigen } \\
\text { and hepatitis } B \text { e antigen }\end{array}$ & $\begin{array}{l}\text { Hepatitis B surface antibody or } \\
\text { hepatitis B core antibody }\end{array}$ & $\begin{array}{l}\text { No } \\
\text { marker }\end{array}$ & \\
\hline $\begin{array}{l}\text { Hepatitis B surface antigen } \\
\text { Hepatitis B surface antigen and hepatitis B e antigen } \\
\text { Hepatitis B surface antibody or hepatitis B core antibody } \\
\text { No marker }\end{array}$ & $\begin{array}{l}3 \\
6 \\
1 \\
3\end{array}$ & 1 & $\begin{array}{r}6 \\
8 \\
14 \\
2\end{array}$ & & $\begin{array}{r}9 \\
14 \\
15 \\
6\end{array}$ \\
\hline Total & 13 & 1 & 30 & & 44 \\
\hline
\end{tabular}

TABLE VI-Concurrence of hepatitis B markers in pairs of siblings (figures are numbers of pairs of siblings)

\begin{tabular}{|c|c|c|c|c|c|}
\hline \multirow[b]{2}{*}{ Younger siblings } & \multicolumn{4}{|c|}{ Elder siblings } & \multirow[b]{2}{*}{ Total } \\
\hline & Hepatitis B surface antigen & $\begin{array}{l}\text { Hepatitis } B \text { surface antigen } \\
\text { and hepatitis } B \text { e antigen }\end{array}$ & $\begin{array}{l}\text { Hepatitis B surface antibody or } \\
\text { hepatitis B core antibody }\end{array}$ & $\begin{array}{c}\text { No } \\
\text { marker }\end{array}$ & \\
\hline $\begin{array}{l}\text { Hepatitis B surface antigen } \\
\text { Hepatitis B surface antigen and hepatitis B e antigen } \\
\text { Antibody } \\
\text { No marker }\end{array}$ & $\begin{array}{l}5 \\
2 \\
5\end{array}$ & $\begin{array}{l}6 \\
2 \\
1\end{array}$ & $\begin{array}{r}2 \\
19 \\
1\end{array}$ & 2 & $\begin{array}{r}7 \\
10 \\
26 \\
2\end{array}$ \\
\hline Total & 12 & 9 & 22 & 2 & 45 \\
\hline
\end{tabular}

detected in all the exudates from subjects who had hepatitis B surface antigen in their blood, and hepatitis B e antigen was detected in both exudates from hepatitis $\mathrm{B}$ e antigen carriers.

Tattoos-Tattooing is a longstanding tradition in these islands. ${ }^{9}$ One hundred and thirteen (59\%) of 193 men aged over 15 and $36(19 \%)$ of 186 women were tattooed. Forty nine $(33 \%)$ of those tattooed carried hepatitis B surface antigen, and $99(66 \%)$ carried antibody markers. In the group who were not tattooed these values were $118 / 397(30 \%)$ and $258 / 397$ $(64 \%)$, respectively. The differences between the two groups were not significant $\left(\chi^{2}=0.4, \mathrm{df}=1, \mathrm{p}>0.5\right.$ and $\chi^{2}=0.01, \mathrm{df}=1, \mathrm{p}>0.5$ for hepatitis $B$ surface antigen and antibody markers, respectively).

Expatriates-Samples from 16 members of the white expatriate population who had been resident in the country for longer than one year were tested. None carried hepatitis B surface antigen, but two were positive for hepatitis B core antibody: one was a doctor and the other was married to a Gilbertese woman.

\section{Discussion}

The prevalence of serum markers of hepatitis B infection in this study is the highest yet reported, with an overall prevalence of $98 \%$. The prevalence of hepatitis B surface antigen is also very high $(31 \%)$. Without random sampling these estimates of hepatitis B virus infection rates may not be truly representative of the whole population of Kiribati, but as they were taken from wide ranging sections of the population and there was no variation among groups a more representative study would probably give similar findings. Because of the limited time and budget of a student elective a population census was not done before the survey. A defined population base was thus not obtained for the study, but only four subjects aged over 10 did not show any marker of infection, indicating that transmission almost always occurs before this age. This indicates that the use of data from adult hospital patients and people in institutions is unlikely to introduce significant bias because infection would have occurred before entry. Most of the children were healthy, attending the clinics for vaccination, with their mothers, or out of curiosity.

The pattern of infection in this population differs from that found in the Polynesian population of Niue, where the prevalence of serum markers increased in a linear fashion from $14 \%$ in children aged under 1 year to $76 \%$ in the $15-19$ year olds, ${ }^{4}$ but was similar to that found in the Solomon Islands, where half of the men and $60 \%$ of the women were infected before the age of $5 .^{5}$ Neither of these studies looked at the prevalence of hepatitis $\mathrm{B}$ e antigen, which is important when considering the source of infection with a view to planning a vaccination strategy.

Blood from patients with detectable hepatitis $B$ e antigen concentrations is thought to be the most potent source of infection by the hepatitis B virus, whether by horizontal routes-for example, by blood transfusion, tattooing, sexual contact, and contaminated needles used by drug addicts ${ }^{10}$ —or by vertical transmission between mother and infant in early childhood or at childbirth." In this population horizontal routes were clearly inapplicable because of the age of infection. The results do not indicate that tattooing carries any increased risk of infection by the hepatitis B virus. Similarly, the analysis of mother-child pairs and the fairly low prevalence of hepatitis B e antigen among mothers of childbearing age indicate that mother to child transmission is not as important as it is in Taiwan and other parts of South East Asia, where transmission of the hepatitis B virus is largely from mothers who are positive for hepatitis B e antigen. ${ }^{12}$ In Kiribati transmission between siblings is probably more important, a problem similar to that reported in the Gambia ${ }^{13}$ and among black children in South Africa. ${ }^{14}$

The finding that exudates of tropical ulcers contain hepatitis $B$ surface antigen and hepatitis $\mathrm{B}$ e antigen provides a clue to how this transmission between siblings may occur. Deoxyribonucleic acid from the hepatitis B virus has been detected in the urine, saliva, and seminal fluid of hepatitis B e antigen carriers ${ }^{15}$; it may also be present in ulcer exudates. Ulcers are very common in the Gilbertese because of their rugged reeftop environment and thus may provide a plentiful source of environmental hepatitis $B$ virus that may infect uninfected people through other ulcers, burrows of scabies mites, or mosquito bites, all of which are common in Gilbertese children. Such a mechanism may also be responsible for the persistent carriage of antibodies to the hepatitis B virus throughout life, as it stimulates natural revaccination. Though not significant, the greater numbers of infected boys in the youngest age group may reflect greater contact during play between boys, who are encouraged to play with their peers outside the family group, while their sisters are often confined to close contact with their mothers until they reach school age (6-7 years).

The relation between the prevalence of chronic hepatitis $B$, hepatocellular carcinoma, and other liver disease, well established in subSaharan Africa and South East Asia, ${ }^{7}$ is also seen in the Pacific islanders. ${ }^{6}$ Accurate statistics are not available for the prevalence of these conditions in Kiribati because of the lack of a diagnostic pathology service on the islands, but clinically they are common and probably add greatly to the workload of the health services. Further 
studies would be necessary to confirm that the results presented here are a true reflection of the prevalence of hepatitis $B$ virus in the whole country and whether tropical ulcers have a role in its transmission. These data, however, indicate the desirability of vaccinating all Gilbertese children against hepatitis $B$ virus at a very early age, preferably at birth, irrespective of maternal hepatitis $\mathrm{B}$ e antigen state. I hope that the price of hepatitis $B$ vaccines will soon be within reach of the modest health budgets of countries such as Kiribati so that this vaccine can be included in the already successful vaccination programme currently instituted by the country's primary health care team.

This survey would have been impossible without the enthusiastic cooperation of everyone I met in Kiribati. I thank Dr T Tetaua, principal medical officer, for permission to work in Kiribati, Mr Tonganabea Taam and Mrs N Tarena for invaluable help with field collections, and Mr T Biribu and staff for laboratory help. I am very grateful to Professor J E Banatvala for his advice and permission to perform the assays in his department. I also thank Drs Joe Cobb and Sue Turner in Kiribati and Professor A J Zuckerman, Mr John Bertram, Miss Asha Senapati, Dr R P H Thompson, and Dr K Cruikshank in England, who gave me invaluable advice and help. I am grateful to Miss Christina Fox and Miss Elaine Ruddock for typing the manuscript.

This work was supported by the Medical Research Council (Rogers Fund), the British Medical Students' Trust, and St Thomas's Hospital Medical School. Equipment was generously supplied by FBG Trident Ltd and reagents by Abbott Laboratories, Chicago.

\section{References}

1 Zhuang H, Coulepis AG, Gust ID, Zimmet P, Taylor R, Nemaia HT. A cross sectional study of markers of hepatitis B infection in Niue. NZ Med J 1983;96:330-2.

2 Gust ID, Dimitrakakis $M$, Bott F, et al. Studies on hepatitis B surface antigen and antibody in Nauru. II. Distribution amongst Gilbert and Ellice (Tuvala) islanders. Am f Trop Med Hyg 1978;27:1206-9.

3 Gust ID, Dimitrakakis M, Zimmet P. Studies on hepatitis B surface antigen in Nauru. I. Distribution amongst Nauruans. Am $\mathcal{F}$ Trop Med Hyg 1981;27:1030-6.

4 Williamson HG, Gust ID, Dimitrakakis M, et al. Serological markers of hepatitis B infection in Niue children. NZ Med f 1985;98:275-7.

5 Mazzur S, Bastiaans MJS, Nath N. Hepatitis B virus (HBV) infection among children and adults in the Solomon Islands. Am $\mathcal{F}$ Epidemiol 1981;113:510-9.

6 Simmons GC, Yeong ML, Lee SP. The association of hepatitis B viral infection and hepatocellular carcinoma in New Zealand. NZ Med f 1983;96:669-71.

7 Zuckerman AJ. Primary hepatocellular carcinoma and hepatitis B virus. Trans $R$ Soc Trop Med Hyg 1982;76:711-8.

8 King H, Taylor R, Zimmet P, et al. Non-insulin-dependent diabetes (NIDDM) in a newly independent Pacific nation: the Republic of Kiribati. Diabetes Care 1984;7:409-15.

9 Gamble A. A pattern of islands. London: John Murray, 1952.

10 Polakoll G. Immunisation of children at high risk of hepatitis B. Br Med $\mathcal{F}$ 1986;285:1294-5.

11 Zuckerman AJ. Priorities for immunisation against hepatitis B. Br Med f 1982;284:686.

12 Beasley RP, Trepo C, Stevens CE, Szmuness W. The e antigen and vertical transmission of hepatitis B surface antigen. Am f Epidemiol 1977;105:94.

13 Whittle HC, McLachlan K, Bradley AK, et al. Hepatitis B infection in two Gambian villages. Lancet 1983; i: 1203-6.

14 Karayiannis P, Novick DM, Lok ASF, Fowler MJF, Moniardino J, Thomas HC. Hepatitis B virus DNA in saliva, urine, and seminal fluid of carriers of hepatitis $\mathrm{B}$ e antigen. $\mathrm{Br}$ Med $\mathcal{J}$ 1985;290:1853-5.

15 Botha JF, Ritchie MJJ, Dusheiko GM, Mouton HWK, Kew MC. Hepatitis B virus carrier state in black children in South Africa. Lancet 1984;i:1210.

(Accepted 25 November 1986)

\title{
Micturition and the mind: psychological factors in the aetiology and treatment of urinary symptoms in women
}

\author{
A J MACAULAY, R S STERN, D M HOLMES, S L STANTON
}

\begin{abstract}
The mental state of 211 women attending a urodynamic clinic was assessed using questionnaires. Patients with genuine stress incontinence had scores comparable with other patients with longstanding physical complaints. Patients with sensory urgency were more anxious than those with genuine stress incontinence. Patients with detrusor instability were as anxious as patients with sensory urgency and in addition had higher scores on the hysteria scale. A subset of patients (roughly a quarter of the total) was identified, comprising members of all three diagnostic groups, for whom urinary symptoms rendered life intolerable. These patients were as anxious, depressed, and phobic as psychiatric inpatients, emphasising the serious psychological morbidity experienced by patients with urinary symptoms.

Fifty patients with detrusor instability or sensory urgency entered a randomised trial comparing psychotherapy, bladder drill, and propantheline. The psychotherapy group significantly
\end{abstract}

Department of Psychiatry, St George's Hospital, Tooting, London SW17 ORE

A J MACAULAY, MSC, MRCPSYCH, senior registrar

R S STERN, MD, FRCPSYCH, consultant psychiatrist

Department of Obstetrics and Gynaecology, St George's Hospital

D M HOLMES, BSC, MRCOG, clinical research fellow

S L STANTON, FRCS, MRCOG, consultant and senior lecturer, urodynamic unit

Correspondence to: Dr Macaulay. improved on measures of urgency, incontinence, and nocturia, though not on frequency. Bladder training was an effective treatment for frequency and patients became less anxious and depressed. There was a modest improvement in frequency of micturition in patients given propantheline.

Frequency may be a learnt disorder which responds to the direct symptom oriented approach of bladder training. Patients with urgency and nocturia predominating might derive more benefit from psychotherapy.

\section{Introduction}

Chronic urgency, frequency, and incontinence are troublesome lower urinary tract symptoms which occur in one fifth of women. ${ }^{1}$ The most important underlying conditions are genuine stress incontinence, idiopathic non-neuropathic detrusor instability, and sensory urgency. Genuine stress incontinence is caused by incompetence of the bladder neck and is conventionally treated by pelvic floor exercises and surgery. Most patients presenting with incontinence have urge type leakage due to sensory urgency or detrusor instability. ${ }^{2}$ The two conditions are distinguished by cystometry, which gives normal results in sensory urgency but shows a pressure rise greater than $15 \mathrm{~cm} \mathrm{H}_{2} \mathrm{O}$ in detrusor instability. Neither disorder responds satisfactorily to conventional management such as surgery or drug treatment. ${ }^{3}$ Psychological approaches have shown some promise. Frewen offered a complete package of inpatient treatment, comprising a bladder diary, bladder retraining, anxiolytic and anticholinergic medication, and supportive care ${ }^{4}$ His results were impressive $(82.5 \%$ of patients cured) but there were insufficient 